\title{
ANTI-ULCER EFFECTS OF 4'-(2-CARBOXYETYL) PHENYL TRANS-4-AMINOMETHYL CYCLOHEXANECARBOXYLATE HYDROCHLORIDE (CETRAXATE) ON VARIOUS EXPERIMENTAL GASTRIC ULCERS IN RATS
}

\author{
Yoshio SUZUKI, Mihoko HAYASHI, Mikio ITO \\ and Ichika YAMAGAMI \\ Department of Pharmacology, Faculty of Pharmacy, Meijo University \\ Nagoya 468, Japan \\ Accepted May 11, 1976
}

\begin{abstract}
Anti-ulecr effects of cetraxate, a new compound possessing anti-plasmin, anti-cascin and anti-trypsin actions were investigated by using experimental gastric ulcer models in rats. Cetraxate, $300 \mathrm{mg} / \mathrm{kg}$ p.o. showed significant inhibitory effects of $65.3 \%, 70.0 \%, 30.2 \%$ and $67.1 \%$ against acute types of uicers producing by aspirin, phenylbutazone, indomcthacin, and pyloric ligature (Shay's ulcer), respectively. These effects were greater than those obtained by gefarnate and aluminum sucrose sulfate and may be mainly attributed to the protecting action of this drug on gastric mucosa. Cetraxate further revealed remarkable inhibitory effects on chronic types of ulcers produced by acetic acid, clamping, and claniping-cortisone. In acctic acid ulcer in particular, cetraxate was found to have a dose-dependent inhibitory effect at doses over $50 \mathrm{mg} / \mathrm{kg}$. Of test drugs including L-glutamine and methylmethionine sulfonium chloride, cetraxate showed the most remarkable inhibitory effect on -glucuronidase activity in ulcer tissuc of these three types of ulcers. These findings suggest that cetraxate may prevent the connective tissue in the ulcer location from decomposition due to lysosomal enzymes such as $\hat{i}$-glucuronidase, thereby accelerating the recovery from ulcer.
\end{abstract}

Cetraxate, 4'-(2-carboxyethyl)phenyl trans-4-aminomethyl cyclohexanecarboxylate hydrochloride (DV-1006), is chemically a o-hydroxyphenyl propionic ester of tranexamic acid (t-AMCHA) and a new compound developed by the collaboration of Muramatsu et al. (1) of Tokushima University and the research laboratory of Daiichi Seiyaku Co (2). This drug was proved in vitro to have more potent anti-plasmin action than t-AMCHA, and also anti-trypsin and anti-kinin actions which t-AMCHA does not possess. Beneficial effects on inflammatory, allergenic or hemorhagic disorders can thus be assumed. We previously reported the effect of this drug on experimental nephritis in rats (3).

The aim of the present study was to determine the anti-ulcer eflects of cetraxate by using various models of experimental gastric ulcers in rats.

\section{MATERIAI.S AND METHODS}

Cetraxate is an odorless compound of white crystals or crystalline powder which is soluble in water and has a slightly bitter tuste. The chenical structure is shown in Fig. 1.

The following drugs were used for comparison: 1-AMCHA (Diiichi Scjyaku), gefarnate 
(gefanil, Sumitomo Kagaku), aluminum sucrose sulfate (ulcerlmin, Chugai Seiyaku), L-glutanine (Kyowa Hakko) and methylmethionine sulfonium chloride (Katayama Kagaku).

Other chemicals used were aspirin (J.P.), phenylbutazone (Fujisawa Yakuhin), indomethacin (Merke-Banyu) and acetic acid (special grade, Katayama Kagaku).

Acute gastric ulcers

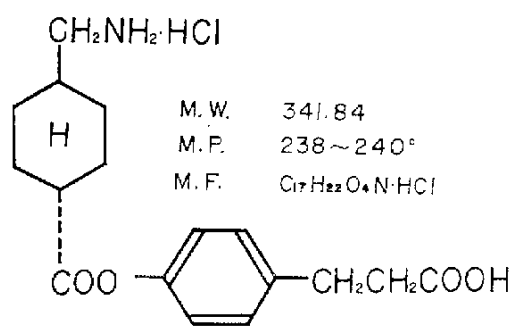

4'-(2-carboxyethyl) phenyl-trans-4-aminomethy] cyclohexanecarboxylate hydrochloride (Cetraxate)

FIf, 1. Chemical structure of cetraxate.

Drug induced ulcers (aspirin, phenylbutazone and indomethacin) (A): Groups of 5 female Wistar rats, weighing about $150 \mathrm{~g}$ were fasted for $20 \mathrm{hr}$ but provided water ad libitum. Thereafter, $10 \mathrm{ml} / \mathrm{kg}$ of each test drug dissolved or suspended in $1 \%$ Gum Arabic solution was given orally. An hour later, gastric ulcers were induced by giving p.o. $300 \mathrm{mg} / \mathrm{kg}$ of aspirin, $200 \mathrm{mg} / \mathrm{kg}$ of phenylbutazone or $25 \mathrm{mg} / \mathrm{kg}$ of indomethacin. Food and watcr were witheld. Five hours after dosing with aspirin, phenylbutazone or indomethacin, the animals were sacrificed under ether anesthesia. Stomachs were removed and incised along the greater curvature. The number of ulcers was counted under a magnifying glass. Each uker was then measured with a caliper to assess the diameter. The cxtent of each ulcer was expressed as the sum of scores described in the following Shay rat ulcer and used as the ulcer index. The percent inhibition of the ulcer index with each test drug was also calculated.

Shay rat ulcer: Groups of 10 female Wistar rats, weighing about $180 \mathrm{~g}$ were fasted for $48 \mathrm{hr}$ but provided water ad libitum. The pylorus was ligated according to the method of Shay et al. (4), and $10 \mathrm{ml} / \mathrm{kg}$ of each test drug dissolved or suspended in $1 \%$ Gum Arabic solution was given p.o. immediately. Eighteen hours later they were sacrificed and the stomachs removed. The number and diameter of ulcers were measured as in (A). The ulcer index was expressed as the sum of scores described below.

Score 1: maximal diameter of $1 \mathrm{~mm}$.

Score 2: maximal diameter of 1-2 $\mathrm{mm}$.

Score 3: maximal diameter of $2-3 \mathrm{~mm}$.

Score 4: maximal diameter of 3-4 $\mathrm{mm}$.

Score 5: maximal diameter of 4-5 $\mathrm{mm}$.

Score 10: an ulcer over $5 \mathrm{~mm}$ in diameter.

Score 25: a perforated ulcer.

In addition to the uleer index, the volume, total acidity and peptic activity of gastric juice were also determined $18 \mathrm{hr}$ after pylorus ligation. Total acidity was determined by titrating undiluted gastric juice centrifuged $(5,000 \mathrm{~g}$ for $20 \mathrm{~min})$ with $0.1 \mathrm{~N} \mathrm{NaOH}$ using phenolphtalein as an indicator. Peptic activity was determined according the method described by Prino et al. (5). Bovine albumin (Katayama Kagaku) was used as substrate, and the unit of enzyme activity was expressed as 4 g tyrosine liberated per $0.1 \mathrm{ml}$ of gastric juice 
for an hour. The percent inhibition of the ulcer index and the volume, total acidity and peptic activity of the gastric juice with each drug was calculated.

Chronic gastric ulcers

Acetic acid ulcer $(A)$; The experiment was carried out according to the method of Takagi et al. (6). Groups of 8 female Wistar rats, weighing about $180 \mathrm{~g}$ were anesthesized with ether, and subjected to laparotomy to expose the stomach after which $0.05 \mathrm{ml}$ of $10 \%$ acetic acid was injected carefully under the serous membrane of the abdominal side in the glandular stomach. The abdomen was closed after adequate disinfection with $1 \%$ acrinol solution. Thereafter, the animals were maintained under normal conditions and administered $10 \mathrm{ml} /$ $\mathrm{kg}$ of each test drug dissolved or suspended in 1\% Gum Arabic solution p.o. daily $\times 8$ starting from the day of the operation. On the 9 th day, they were sacrificed under ether anesthesia, stomachs were removed and incised along the greater curvature. The longitudinal and abscissal lengths of the ulcer areas were quickly measured with a caliper, and the multiplied product was used as the ulcer index. In addition to the ulcer index, the activity of $\beta$-glucuronidase ( $\beta$-Gase) in the gastric tissue was also determined in accordance with the following procedure: As soon as possible after the ulcer index was measured, the glandular stomach was weighed, 10 vol. of physiological saline solution was added and under a cold condition the tissuc cut into pieces with scissors. The tissue was homogenized by using Polyton of PT $200 \mathrm{D}$ typc under cooling and the homogenate was then centrifuged at 12,000 r.p.m. at $4^{\circ} \mathrm{C}$ for $20 \mathrm{~min}$. The supernatant was collected, filtrated and diluted with physiological saline solution to make an adequate concentration after which it was used for enzyme assay. $\beta$-Gasc activity was determined in accordance with the method described in our earlier report (7). For the determination of this enzyme, $\rho$-nitrophenyl glucuronide (Chugai Seiyaku) was used as substrate. The unit of enzyme activity was expressed as $\mu \mathrm{g}$ $\rho$-nitrophenol liberated per mg protein for one hour.

Clamping ulcer $(B)$ : The test was carried out in accordance with the method of Umehara et al. (8). Groups of 8 female Wistar rats, weighing about $200 \mathrm{~g}$, were subjected to laparotomy under ether anesthesia following a fast of $24 \mathrm{hr}$. The stomachs were cxposured, and clamping was done at the area $3 \mathrm{~mm}$ from the forcgut boundary at the grcater curvature side loward the pyrolus by pressing with a two-fold aluminium plate $4 \times 12 \mathrm{~mm}$ in size after two sheets of gauze had been placed. The abdomen was closed after disinfection with $1 \%$ acrinol solution. Twenty-four hours later the abdomen was again opened to remove the aluminium plate and gauze. A normal diet was provided to these postopcrative animals. For supply of nutriments, $10 \mathrm{ml}$ of $5 \%$ glucose solution was given s.c. for 3 consecutive days from the fasting day. Each test drug was dissolved or suspended in $1 \%$ Gum Arabic solution and $10 \mathrm{ml} / \mathrm{kg}$ p.o. daily was given for 14 days from the day of the removal of aluminium plate. On the 15 th day, these animals were sacrificed under ether anesthesia. The stomachs were removed to determine the ulcer index and $\beta$-glucuronidase activity in the gastric tissue as in $(A)$. The percent inhibition of the ulcer index and enzyme activity with cach drug was calculated.

Clamping-cortison ulecr (8): Clamping was made by the same procedure as deseribed 
in (B). A daily i.m. injection of $5 \mathrm{mg} / \mathrm{kg}$ of hydrocortisone was carried out for 7 days starting from the day of removal of aluminium plate. Each test drug was dissolved or suspended in $1 \%$ Gum Arabic solution and $10 \mathrm{ml} / \mathrm{kg}$ p.o. for 11 consecutive days was given starting the day after the last day of hydrocortisone injections. Twenty-four hours later these rats were sacrificed under ether ancsthesia, and the stomachs were removed. The ulcer index and $\beta$-Gase activity in the gastric tissue were determined and categorized as in ( $A$ ). The percent inhibition with each drug was calculated.

The results of the above experiments were statistically evaluated using Student's t-test.

\section{RESULTS}

Anti-ulcer effects of cetraxate on acute gastric ulcers

Inhibitory effect on aspirin ulcer: As shown in Table 1, the inhibitory effect of cetraxate on aspirin ulcer was not observed with a dose of $50 \mathrm{mg} / \mathrm{kg} \mathrm{p} .0$. while $300 \mathrm{mg} / \mathrm{kg} \mathrm{p.o.} \mathrm{of} \mathrm{the}$ drug showed a significant inhibitory effect of $65.3 \%(p<0.01)$. Gefarnate $100 \mathrm{mg} / \mathrm{kg}$ p.o. and aluminum sucrose sulfate $1,000 \mathrm{mg} / \mathrm{kg}$ p.o. also exhibited the inhibitory effect of $42.8^{\circ} \mathrm{o}$ $(\mathrm{p}<0.05)$ and $38.6 \%(\mathrm{p}<0.01)$, respcctively.

TABLE 1. Inhibitory effects of cetraxate, gefarnate and aluminum sucrose sulfate on aspirin ulcer in rats

\begin{tabular}{lrlr}
\hline Drugs & $\begin{array}{c}\text { Dose } \\
\text { mg:kg, p.o. }\end{array}$ & $\begin{array}{l}\text { Ulcer index } \\
\text { mean } \pm \text { S.I }\end{array}$ & $\%$ inhibition \\
Control & $(5)$ & $56.0=8.6$ & \\
Cetraxate & $50(5)$ & $52.3 \pm 6.6$ & 6.4 \\
& $300(5)$ & $19.4 \pm 2.8^{* * *}$ & 65.3 \\
Gefarnate & $100(5)$ & $32.0 \pm 8.0^{*}$ & 42.8 \\
Aluminum sucrose sulfate & $1000(5)$ & $34.4 \pm 1.4^{* *}$ & 38.6 \\
\hline
\end{tabular}

( ), Number of rats. *, Significant difference from control $(p<0.05)$. **, Significant difference from control $(p<0.01)$.

Inhibitory effect on phenylbutazone uleer: As shown in Table 2, cetraxate $300 \mathrm{mg} / \mathrm{kg}$ resulted in a remarkable inhibitory effect of $70.0 \%(\mathrm{p}<0.01)$ on phenylbutazone ulcer. Gefarnate $100 \mathrm{mg} / \mathrm{kg}$ p.o. and aluminum sucrose sulfate $1,000 \mathrm{mg} / \mathrm{kg}$ p.o. showed the inhibitory effects of $31.5 \%(\mathrm{p}<0.01)$ and $38.0 \%(\mathrm{p}<0.01)$, respectively.

TABLE 2. Inhibitory effects of ectraxatc, gefarmate and aluminum sucrose sulfate on phenylbutazone ulcer in rats

\begin{tabular}{|c|c|c|c|}
\hline Drugs & $\begin{array}{c}\text { Dose } \\
\text { mg kg, p.o. }\end{array}$ & $\begin{array}{l}\text { Ulcer index } \\
\text { mean S.E. }\end{array}$ & $\%$ intribition \\
\hline Control & $(5)$ & $44.0 \perp 2.8$ & \\
\hline \multirow[t]{2}{*}{ Cetraxate } & $50(5)$ & $40.5: 4.6$ & 8.0 \\
\hline & $300(5)$ & $13.2 \therefore 3.3^{\text {knt }}$ & 70.0 \\
\hline Gufarmate & $100(5)$ & $30,1 \cdot 1,4^{*}$ & 31.5 \\
\hline Aluminum sucrose sulfate & $1000(5)$ & $27.3 \quad 1.7^{* *}$ & 38.1 \\
\hline
\end{tabular}

( ), Number of rats. **, Significant difference from control (p 0.01). 
Inhibitory effect on indomethacin wicer: As shown in Table 3, cetraxate at a dose of $50 \mathrm{mg} / \mathrm{kg}$ p.o. had no inhibitory clicel on indomethacin ulcer as in other types of drug ulcers, but at a dose of $300 \mathrm{mg} / \mathrm{kg}$ p.o., there was a significant inhibitory effect of $30.2 \%$ (p 0.01 ). Gefarnate $100 \mathrm{mg} / \mathrm{kg}$ p.o. and aluminum sucrose sulfate $1,000 \mathrm{mg} / \mathrm{kg}$ p.o. also exhibited inhibitory effects of $29.0 \%(\mathrm{p}<0.05)$ and $40.0 \%(\mathrm{p}-0.01)$, respectively.

TABuE 3. Inhibitory effects of cerraxate, gefarnate and aluninum sucrose sulfate on indomethacin ulcer in rats

\begin{tabular}{lclc}
\hline Drugs & $\begin{array}{c}\text { Dose } \\
\text { mg/kg, p.o. }\end{array}$ & $\begin{array}{l}\text { Ulcer index } \\
\text { nean S.E. }\end{array}$ & $\%$ inhibition \\
Control & $(5)$ & $29.0 \pm 2.0$ & \\
Cetraxate & $50(5)$ & $27.6 \pm 2.7$ & 4.8 \\
& $300(5)$ & $20.2 \div 1.4^{* *}$ & 30.2 \\
Gefarnate & $100(5)$ & $20.6 \pm 5.1^{*}$ & 29.0 \\
Aluminum sucrose sulfate & $1000(5)$ & $17.4 \div 0.9^{* *}$ & 40.0 \\
\hline
\end{tabular}

( ), Number of rats. *, Significant difference from control $(1<<0.05)$, **, Significant difference from control $(\mathrm{p}-0.01)$.

Ithibitory effect on Shay rat ulcer: As shown in Table 4, cetraxate at doses of 50 and $300 \mathrm{mg} / \mathrm{kg}$ p.o. showed signinicant inhibitory effects of $35.0 \%(\mathrm{p} \quad 0.05)$ and $67.1 \%(\mathrm{p} \quad 0.001)$ on ulcer index, respectively. Gefarnate $100 \mathrm{mg} / \mathrm{kg} \mathrm{p.o.} \mathrm{and} \mathrm{aluminum} \mathrm{sucrose} \mathrm{sulfate} 1,000$ mg: $\mathrm{kg}$ p.o. also exhibited a strong inhibitory effect over $80 \%(\mathrm{p}<0.001)$. In contrast to the effect, cetraxate $50 \mathrm{mg} / \mathrm{kg}$ or $300 \mathrm{mg} / \mathrm{kg}$ p.o. did not affect either the volume or total acidity of gastric juice, but at a dose of $300 \mathrm{mg} / \mathrm{kg}$ p.o. there was a slight inhibitory effect of $17.0 \%$ (p 0.05 ) on peptic activity. Gefarnate $100 \mathrm{mg} / \mathrm{kg} \mathrm{p.o.} \mathrm{failed} \mathrm{to} \mathrm{inhibit} \mathrm{these} \mathrm{three} \mathrm{parameters}$ in gastric juice. However, aluminum sucrose sulfate at a dose of $1,000 \mathrm{mg} / \mathrm{kg} \mathrm{p.o.} \mathrm{had} \mathrm{strong}$ inhibitory effects of $65.0 \%(\mathrm{p}<0.001)$ and $77.9 \%(\mathrm{p}<0.001)$, respectively, on both the total acidity and peptic activity of gastric juice, although no effect was seen on gastric secretion. Anti-ulcer effects of cetraxate on chronic gastric ulcers

Inhibitory effects on ulcer index and B-Gase activity in wher tissue of ace tic acid ulcer: Following daily oral administrations for 8 successive days, cetraxate at doses of $50 \mathrm{mg} / \mathrm{kg}$, $100 \mathrm{mg} / \mathrm{kg}$ and $300 \mathrm{mg} / \mathrm{kg}$ a day showed inhibitory effects of $22.7 \%, 47.3 \%(\mathrm{p}<0.05)$ and $63.7 \%(\mathrm{p} 0.01$ ) on ulcer index, respectively (Table 5). This drug at doses of $100 \mathrm{mg} / \mathrm{kg}$ and $300 \mathrm{mg} / \mathrm{kg}$ daily brought about significant inhibitory effects of $21.4 \%(\mathrm{p}<0.05)$ and $41.5 \%$ ( $p$ 0.01) against $\beta$-Gase activity, respectively. Of drugs used for a comparison, t-AMCHA $500 \mathrm{mg} / \mathrm{kg}$ day showed no inhibitory effects on either the ulcer index or $\beta$-Gase activity, while gefarnate $200 \mathrm{mg} / \mathrm{kg} / \mathrm{day}$ showed a significant inhibition of $22.1 \%(p<0.05)$ against , 3 -Gase activity. Aluminum sucrose sulfate $1,000 \mathrm{mg} / \mathrm{kg} / \mathrm{day}$ and L-glutamine 500 mg kg'day exhibited inhibitions of $47.3 \%(\mathrm{p}<0.05)$ and $56.6 \%(\mathrm{p}<0.01)$, respectively, on ulcer index, while only L-glutamine showed a significant inhibition of $18.9 \%(p<0.05)$ on 3 -Gase activity. Methylmethionine sulfonium chloride $50 \mathrm{mg} / \mathrm{kg} /$ day caused an inhibition of $49.1 \%(\mathrm{p}<0.01)$ on uker index and $17.3 \%(\mathrm{p}<0.05)$ on $\beta$-Gase activity. 


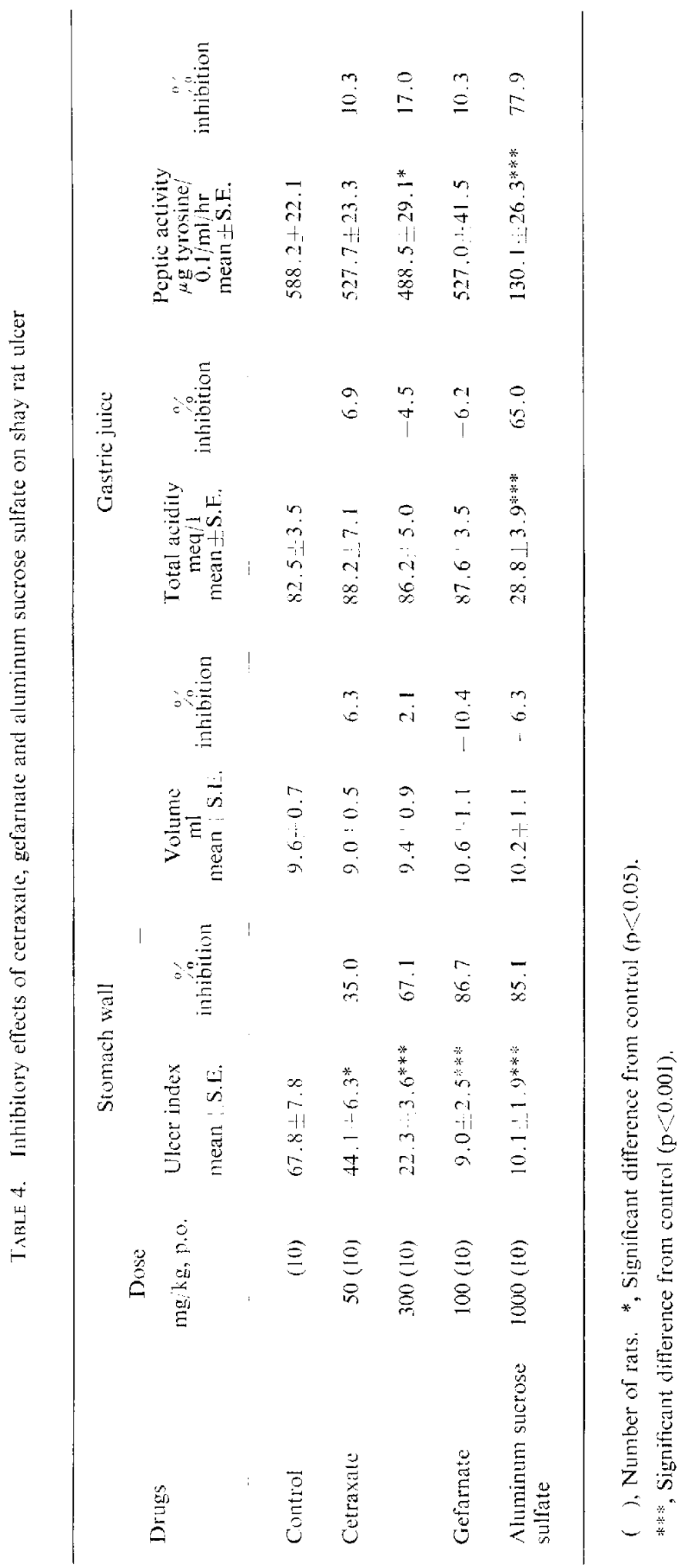


TABLE 5. Inhibitory effects of cetraxate and several drugs on ulcer index and 3-gluculonidase activity in ulcer tissue of acetic acid ulcer in rats

\begin{tabular}{|c|c|c|c|c|c|}
\hline \multirow[b]{2}{*}{ Drugs } & \multirow{2}{*}{$\begin{array}{l}\text { Dose } \\
\mathrm{mg} / \mathrm{kg}, \text { p.o. } \\
\times 8 \text { days }\end{array}$} & \multicolumn{2}{|c|}{ Lilcer index } & \multicolumn{2}{|c|}{$\beta$-glucuronidase activity } \\
\hline & & $\begin{array}{c}\text { Index } \\
\text { mean }\end{array}$ & $\begin{array}{c}\% \\
\text { healing rate }\end{array}$ & $\begin{array}{l}\mu \mathrm{g} g \text {-nitrophenol } \\
\text { /mg protein'hr } \\
\text { mean } \pm \mathrm{S.E.}\end{array}$ & inhibition \\
\hline Control & (8) & $25.1 \mathrm{l}=8.5$ & & $38.1: 3.7$ & \\
\hline Cetraxatc & $50(8)$ & $19.4 \pm 10.3$ & 22.7 & $32.5-3.8$ & 14.7 \\
\hline Control & (8) & $27.0^{\prime}-3.4$ & & $27.7 \pm 2.3$ & \\
\hline Cetraxate & $100(8)$ & $14.2 ! 1.8^{*}$ & 47.3 & $21.9 \pm 1.7^{*}$ & 21.4 \\
\hline $\begin{array}{l}\text { Control } \\
\text { Cetraxate }\end{array}$ & $300 \stackrel{(8)}{(8)}$ & $\begin{aligned} 25.1 & =8.5 \\
9.1 & =0.1^{* *}\end{aligned}$ & 63.7 & $\begin{array}{l}38.1 \pm 3.7 \\
22.3 \pm 3.5^{* k}\end{array}$ & 41.5 \\
\hline $\begin{array}{l}\text { Control } \\
\text { Gefarnate }\end{array}$ & $100 \stackrel{(8)}{(8)}$ & $\begin{array}{l}25.7 \div 2.9 \\
22.9 \div 6.8\end{array}$ & 10.5 & $\begin{array}{l}34.2 \div 2.6 \\
33.9+4.1\end{array}$ & 0.8 \\
\hline $\begin{array}{l}\text { Control } \\
\text { Gefarnate }\end{array}$ & $200 \stackrel{(8)}{(8)}$ & $\begin{array}{l}23.9 \pm 9.4 \\
17.4 ! 8.1\end{array}$ & 27.1 & $\begin{array}{l}27.2 \div 3.4 \\
21.2 \div 1.3 *\end{array}$ & 22.1 \\
\hline $\begin{array}{l}\text { Control } \\
\text { Aluminum sucrose } \\
\text { sulfate }\end{array}$ & $1000(8)$ & $\begin{array}{l}28.5-2.1 \\
15.0 \div 0.4^{*}\end{array}$ & 47.3 & $\begin{array}{l}33.4 \pm 4.5 \\
30.2 \pm 5.5\end{array}$ & 9.6 \\
\hline $\begin{array}{l}\text { Control } \\
\text { L-giutamine }\end{array}$ & $500 \stackrel{(8)}{(8)}$ & $\begin{array}{l}25.1 \pm 8.5 \\
10.9 \cdots 0.2^{*}\end{array}$ & 56.6 & $\begin{array}{l}38.1+3.7 \\
30.9 \pm 1.3^{*}\end{array}$ & 18.9 \\
\hline Control & (8) & $27.0: 3.4$ & & $27.8 \pm 2.3$ & \\
\hline $\begin{array}{l}\text { Methylmethionine } \\
\text { sulfonium chloride }\end{array}$ & $50(8)$ & $13.7+2.6^{* * *}$ & 49.1 & $23.0 \perp 1.5^{*}$ & 17.3 \\
\hline Control & (8) & $27.0 \leq 3.4$ & & $27.8 \perp 2.3$ & \\
\hline t-AMCHA & $500(8)$ & $23.6 \div 2.4$ & 12.7 & $24.6+2.1$ & 11.7 \\
\hline
\end{tabular}

( ), Number of rats. ", Significant diflerence from control (p 0.05). **, Significant difference from control $(\mathrm{p}<0.01)$.

Inhibitory effects on ulcer index and $\beta$-Gase activity in ulcer tissue of clamping ulcer: Following daily oral administrations for 14 consecutive days, cetraxate $200 \mathrm{mg} / \mathrm{kg} / \mathrm{day}$ caused inhibitory effects of $63.8 \%(\mathrm{p}<0.05)$ on ulcer index and $35.9 \%(\mathrm{p}<0.05)$ on $\beta$-Gase activity, respectively (Table 6). The daily administrations of gefarnate $100 \mathrm{mg} / \mathrm{kg}$ and L-glutamine $500 \mathrm{mg} / \mathrm{kg}$ induced significant inhibitory effects of $67.3 \%(\mathrm{p}<0.05)$ and $44.3 \%(\mathrm{p}<0.05)$ on ulcer index, respectively. However, aluminum sucrose sulfate $1,000 \mathrm{mg} / \mathrm{kg} / \mathrm{day}$ and methylmethionine sulfonium chloride $50 \mathrm{mg} / \mathrm{kg} / \mathrm{day}$ had no significant inhibition. Against $\beta$-Gase activity gefarnate $100 \mathrm{mg} / \mathrm{kg} /$ day, L-glutamine $500 \mathrm{mg} / \mathrm{kg} /$ day and methylmethionine sulfonium chloride $50 \mathrm{mg} / \mathrm{kg} /$ day brought about significant inhibitions of $13.2 \%(\mathrm{p}<0.05)$, $14.7 \%(p-0.05)$ and $26.6 \%(p<0.05)$, respectively. Only aluminum sucrose sulfate 1,000 $\mathrm{mg} / \mathrm{kg} / \mathrm{day}$ increased this enzyme activity by $48.5 \%(\mathrm{p}<0.01)$.

Inhibitory effects on ulcer index and $\beta$-Gase activity in ulcer tissue of clamping-cortisone ulcer: Following daily oral administrations for 12 consecutive days, cetraxate $200 \mathrm{mg} / \mathrm{kg}$ / day showed inhibitory effects of $37.6 \%(p<0.05)$ on ulcer index and $32.4 \%(p<0.01)$ on $\beta$-Gase activity, respectively (Table 7). Among compared drugs, only L-glutamine 500 
TABLF 6. Inhibitory effects of cetraxate and scveral drugs on ulcer index and i-glucuronidase activity in ulcer tissue of clamping ulcer in rats

\begin{tabular}{|c|c|c|c|c|c|}
\hline \multirow[b]{2}{*}{ Drugs } & Dose & \multicolumn{2}{|c|}{ Uleer index } & \multicolumn{2}{|c|}{-glucuronidase activity } \\
\hline & $\begin{array}{l}\text { mgikg, p.o. } \\
\because 14 \text { days }\end{array}$ & $\begin{array}{c}\text { Index } \\
\text { mean } \perp \text { S.E. }\end{array}$ & healing rate & $\begin{array}{l}\mu \mathrm{g} \rho \text {-nitrophenol } \\
\text { mg protein } / \mathrm{hr} \\
\text { mean }=\mathrm{S} . \mathrm{E} .\end{array}$ & inhibition \\
\hline Control & (8) & $50.0+15.6$ & & $38.7 \pm 6.0$ & \\
\hline Cetraxate & $200(8)$ & $18.1 \% 3.1 *$ & 63.8 & $24.8=1.2^{*}$ & 35.9 \\
\hline Control & (8) & $50.0 \pm 15.6$ & & $38.7-6.0$ & \\
\hline Gefarnate & $100(8)$ & $16.4 \pm 2.3^{*}$ & 67.3 & $33.6 \pm 2.9^{*}$ & 13.2 \\
\hline Control & (8) & $47.4+15.5$ & & $38.9 \pm 2.2$ & \\
\hline $\begin{array}{l}\text { Aluminum sucrose } \\
\text { sulfate }\end{array}$ & $1000(8)$ & $33.6 \pm 19.8$ & 29.1 & $57.8 \doteq 5.2^{* *}$ & -48.5 \\
\hline Control & (8) & $47.4 \pm 15.5$ & & $38.9 \div 2.2$ & \\
\hline L-glutamine & $500(8)$ & $26.9 \doteq 6.0^{*}$ & 44.3 & $33.2 \pm 0.9^{*}$ & 14.7 \\
\hline Control & (8) & $44.0 \pm 12.6$ & & $26.7 \pm 1.7$ & \\
\hline $\begin{array}{l}\text { Methylmethionine } \\
\text { sulfonium chloride }\end{array}$ & $50(8)$ & $28.0-11.6$ & 36.4 & $19.6 \pm 1.9 \%$ & 26.6 \\
\hline
\end{tabular}

( ), Number of rats. *, Significant difference from control $(p<0.05)$. **, Significant difference from control $(p<0.01)$.

TABLt: 7. Inhibitory effeets of ceiraxate and several drugs on ulcer index and $\beta$-glucuronidase activity in ulcer tissue of clamping cortisone ulcer in rats

\begin{tabular}{|c|c|c|c|c|c|}
\hline \multirow[b]{2}{*}{ Drulgs } & \multirow{2}{*}{$\begin{array}{c}\text { Dose } \\
\text { mg:kg, p.o. } \\
\times 12 \text { days }\end{array}$} & \multicolumn{2}{|c|}{ Ulecr index } & \multicolumn{2}{|c|}{$\beta$-glucuronidase activity } \\
\hline & & $\begin{array}{c}\text { Index } \\
\text { mean:-S.E. }\end{array}$ & healing rate & $\begin{array}{l}\mu \mathrm{g} \rho \text {-nitrophenot } \\
\text { /mg protein/hr } \\
\text { mean } \pm \text {-S.E. }\end{array}$ & inhibition \\
\hline Control & (8) & $9.3 \pm 2.4$ & & $56.1=4.4$ & \\
\hline Cetraxate & $200(8)$ & $5.8 \pm 0.5^{\%}$ & 37.6 & $37.9 \div 3.2^{* *}$ & 32.4 \\
\hline Gefarnate & $100(8)$ & $6.1-1.4$ & 34.4 & $52.2 \div 5.3$ & 7.0 \\
\hline $\begin{array}{l}\text { Aluminum sucrose } \\
\text { sulfate }\end{array}$ & $1000(8)$ & $9.3 \div 3.4$ & 0 & $70.8+9.3$ & -26.2 \\
\hline L-glutamine & $500(8)$ & $3.5-0.8^{k}$ & 62.4 & $41.4 \div 3.5^{*}$ & 26.2 \\
\hline $\begin{array}{l}\text { Methylmethionine } \\
\text { sulfonium chloride }\end{array}$ & $50(8)$ & $7.4=1.0$ & 20.4 & $49.7 \pm 4.5$ & 11.4 \\
\hline
\end{tabular}

( ), Number of rats. *, Significant difference from control $(\mathrm{p}<0.05),{ }^{* *}$, Significant difference from control $(p<0.01)$.

$\mathrm{mg} / \mathrm{kg} / \mathrm{day}$ caused significant inhibitions of $62.4 \%(\mathrm{p}<0.01)$ and $26.2 \%(\mathrm{p}<0.05)$ against both ulcer index and $\beta$-Gase activity, respectively.

\section{DISCUSSION}

The p.o. administration of $300 \mathrm{mg} / \mathrm{kg}$ of cetraxate inhibited acute gastric ulcers induced by aspirin, phenylbutazone and indomethacin. The mechanism of development of aspirin ulcer has been claimed to be primarily due to the direct irritation to gastric mucosa and 
partialiy due to the disturbance of the gastric mucosal barrier by the back diffusion of gastric acid (9). In the light of the marked inhibitory effect of cetraxate on aspirin ulcer, it may be assumed that this drug has a protective effect similar to that of L-glutamine on the gastric mucosal barrier.

Shay's ulcer induced by pylorus ligation is considered to be unsuitable as a model of gastric ulcer, since the ulceration develops in the forestomach. However, this method can serve for detecting drugs which are effective in eliminating the aggressive factors such as pepsin and $\mathrm{HCl}$ in gastric juice, as the mechanism of ulceration for this model may be attributed mainly to the digestive action of gastric juice. Okabe (10) reported that pepsin is probably a more important factor than gastric juice in Shay's ulcer. Cetraxale $300 \mathrm{mg} / \mathrm{kg}$ p.o. significantly inhibited the peptic activity of gastric juice $18 \mathrm{hr}$ after pylorus ligation, while the volume and the total acidity remained unaffected. Fujii ct al. found that cetraxate at a concentration of $10^{-}-\mathrm{M}$ remarkably inhibited peptic activity, the decrease of $\mathrm{pH}$ and the increase of $\mathrm{Cl}^{-}$following the perfusion of tetragastrin through the stomach in rats (personal communication). Therefore, cetraxate may partially inhibit this experimental ulcer through its anti-peptic activity. We previously reported that increased activity of mucopolysaccharase such as $\beta$-Gase was evident in the ulcer tissue of chronic types of gastric ulcers induced by acetic acid, clamping or clamping-cortisone, but not in acute types of ulcers induced by anti-inflammatory drugs or pylorus ligation (7). We assumed that in these chronic types of ulcers, $\beta$-Gase might be liberated from lisosomes of necrotic cells in the gastric tissue subjected to a severe injury by the injection of acetic acid or by clamping with aluminium plate and would bring about the destruction of the normal tissue surrounding the necrotic wound. Therefore, $\beta$-Gase aclivity in ulcer tissue may reffect the extent of the lesion of gastric tissue. In the present experiment, cetraxate was effective in inhibiting both the uker index and $\beta-$ Gase activity of ulcer tissue in models of these chronic ulcers, suggesting that this drug may prevent destruction of gastric tissue due to lysosonal enzyme such as $\beta$-Gase. Fukawa et al. (11) reported that drugs such as antacids, anticholinergic agents and anti-pepsin agents which eliminate the aggressive factors were ineffective on acetic acid ulcer, whereas the therapeutic efficacy was observed with drugs such as L-glutamine and methylmethionine sulfonium chloride which are known to promote the regeneration of mucosa and the formation of granuloma tissue. Thus cetraxate also may be active in promoting the acceleration of ulcer healing.

The relationship between gastric ulcer and the fibrinolytic activity is now frequently discussed and Abe et al. (12) reported that fibrinolytic activity was elevated at the ulcer region in the gastric ulcer produced by immersing rats in cold water. Kondo et al. (13) reported that the local fibrinolytic activity in the gastric ulcer induced by the injection of immunocomplex in dogs was elevated up to 9 times the normal level after $2 \mathrm{hr}$, and 8 and 4 times more than the normal after 12 and $24 \mathrm{hr}$, respectively. The possible effect of cetraxate in viro on local fibrinolytic activity is under investigation by our team. In view of the results obtained in vitro, cetraxate may also have inhibitory effects on the elevation of fibrinolytic activity in ulcer tissue. 
Yokoyama suggested that cetraxate might have a strong affinity to gastric mucosa from results obtained by the systemic autoradiographic method in rats which showed that this agent was retained longer in the stomach (personal communication).

From these findings, cetraxate proved to be applicable for clinical therapy as it had not only the promoting effect on the prevention and healing of the ulcer itself, but also a hemostatic effect.

\section{REFERENCES}

1) Mlramatsu, M. and Fuji, S.: Biochim. Biophys. Acta 242, 222 (1971)

2) Okano, A., Inaoka, M., Funabasiir, S., Iwamoto, M., Isoda, S., Moror, R., Abiko, Y. and HiRata, M.: J. med. Chem. 15, 247 (1972)

3) Suzuki, Y., Ina, K., Kohara, U. and Yamagami, I. : Folia pharmacol. japon. 68, 226 (1972) (in Japanese)

4) ShnY, H., Komarov, S.A. and Fels, S.S.: Gastroenterology 5, 43 (1945)

5) Prino, G., Paglialunga, S., Nardi, G. And Lietti, A.: Europ. J. Pharmacol. 15, 119 (1971)

6) TAKaGi, K., OKabi, S. AND SAZIKI, R.: Japan. J. Pharmacol. 19, 418 (1969)

7) Suzuki, Y., Hayashi, M., Hamaguchi, Y., Ito, M. and Yamagami, I.: Pharmacometrics 12, No. 1 (1976) (in press)

8) Umehara, S., Tabayashi, T., Shibuya, E. and Ito, Y.: Medicine and Biology 66, 7 (1960) (in Japanese)

9) Davenport, H.W.: Gastroenterology 46, 245 (1964)

10) OKabe, S.: J. Pr. Ph. 25, 54 (1974) (in Japanese)

11) Fukawa, K., Irino, O., Ito, Y., Misaki, N. and Nomura, F.: Pharmacometrics 7, 1329 (1973) (in Japanese)

12) Abe, H., Matsuo, Y. and Yutani, M.: Reports from 10th Meeting of Plasmin, p. 142 (1970) (in Japunese)

13) Kondo, K., Kawai, K. ANd Masuda, M.: Japan. J. dig. Dis. 71, 41 (1974) (in Japanese) 